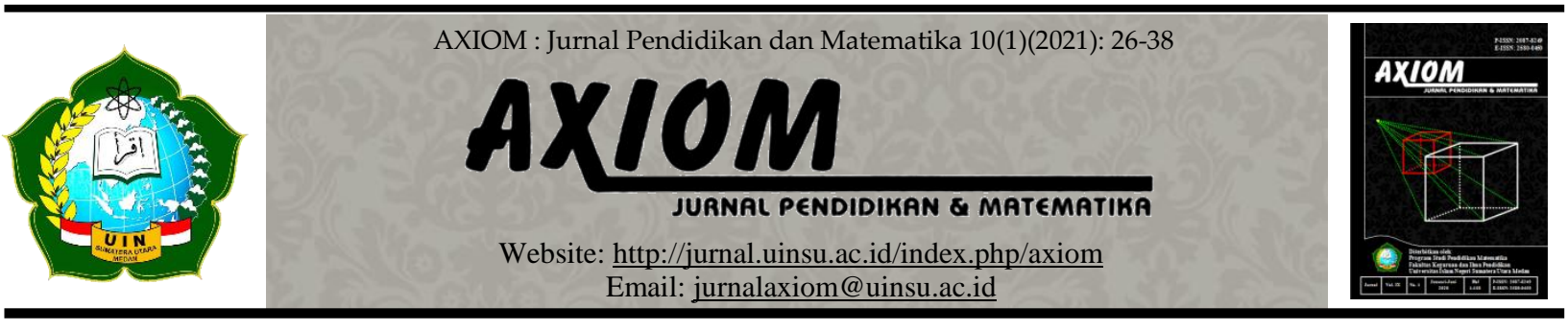

\title{
ANALISIS FAKTOR-FAKTOR YANG MEMPENGARUHI TINGKAT KEPUASAN MAHASISWA TERHADAP PEMILIHAN PROGRAM STUDI MATEMATIKA UINSA SURABAYA MENGGUNAKAN METODE REGRESI LOGISTIK ORDINAL
}

Oleh:

\author{
Fadillahtur Rizka Nur Rian ${ }^{1}$, Moch. Hafiyusholeh ${ }^{2}$ \\ ${ }^{1}$ Mahasiswa Program Studi Matematika Fakultas Sains dan Teknologi UIN Sunan Ampel \\ Surabaya \\ ${ }^{2}$ Dosen Program Studi Matematika Fakultas Sains dan Teknologi UIN Sunan Ampel Surabaya \\ E-mail: ${ }^{1}$ fadillahturrizka4892@gmail.com, ${ }^{2}$ hafiyusholeh@uinsby.ac.id
}

\section{doi : 10.30821/axiom.v10i1.8072}

\begin{abstract}
Abstrak:
Penelitian ini bertujuan untuk mengetahui model logit kumulatif dan faktor-faktor yang mempengaruhi tingkat kepuasan mahasiswa terhadap pemilihan program studi matematika UIN Sunan Ampel Surabaya. Data dianalisis menggunakan metode regresi logistik ordinal dengan tahapan penelitian yaitu pembentukan model logit kumulatif, uji kesesuaian model, uji parameter (serentak dan parsial) dan uji koefisien determinasi model. Variabel yang digunakan adalah citra program studi, fasilitas pendidikan, minat dan bakat, biaya pendidikan, prospek program studi, dan faktor sosial. Data yang digunakan dalam penelitian yaitu menggunakan kuisioner atau angket yang akan disebarkan kepada mahasiswa program studi matematika angkatan 2016 s.d. 2019 . Hasil penelitian menunjukkan bahwa nilai uji kesesuaian model goodness of fit test adalah $\chi_{\text {hitung }}^{2}=12,294<\chi_{\text {tabel }}^{2}=122,10773$ yang dapat disimpulkan bahwa model regresi logistik ordinal dinyatakan sesuai untuk digunakan. Model logit kumulatif dari regresi logistik ordinal terhadap faktor-faktor yang mempengaruhi tingkat kepuasan mahasiswa terhadap pemilihan program studi matematika UINSA Surabaya yaitu:

1. Logit $P\left(Y \leq j \mid X_{i}\right)=36,878+10,809 X_{1}+3,230 X_{2}+2,580 X_{3}+1,774 X_{4}+2,505$

$$
\mathrm{X}_{5}+1,795 \mathrm{X}_{6}
$$

2. Logit $P\left(Y \leq j \mid X_{i}\right)=63,878+10,809 X_{1}+3,230 X_{2}+2,580 X_{3}+1,774 X_{4}+2,505$

$$
\mathrm{X}_{5}+1,795 \mathrm{X}_{6}
$$

Adapun faktor-faktor lain yang berpengaruh secara signifikan dalam pemilihan program studi matematika diperoleh dari hasil uji parameter secara parsial adalah fasilitas pendidikan sebesar 6,250 dan minat bakat sebesar $3,870>\chi^{2}$ tabel $(0,05,1)=3,841$ yang artinya terdapat satu atau lebih variabel yang berpengaruh secara signifikan. Secara keseluruhan variabel independen mempengaruhi penilaian kepuasan mahasiswa terhadap pemilihan program studi matematika UINSA Surabaya sebesar $94,8 \%$ dan 5,2\% dipengaruhi oleh faktor lain.
\end{abstract}

\section{Kata Kunci:}

Logit Kumulatif , Pemilihan Program Studi, Regresi Logistik Ordinal 
Abstract:

This study aims to determine the cumulative logit model and the factors that affect the level of student satisfaction with the selection of the mathematics study program at UIN Sunan Ampel Surabaya. The data were analyzed using the ordinal logistic regression method with the stages of research, namely the formation of a cumulative logit model, model suitability test, parameter test (concurrent and partial) and model determination coefficient test. The variables used are the image of the study program, educational facilities, interests and talents, tuition fees, prospects for study programs, and social factors. The data used in the research is using a questionnaire or questionnaire that will be distributed to students of the 2016 s.d 2019 batch of mathematics study program. The results showed that the value of the goodness of fit test model suitability test was $\chi_{\text {hitung }}^{2}=12.294<\chi_{\text {tabel }}^{2}=122.10773$, which can be concluded that the ordinal logistic regression model was declared suitable for use. The cumulative logit model of ordinal logistic regression on the factors that affect the level of student satisfaction with the selection of the mathematics study program at UINSA Surabaya, namely:

1. Logit $P\left(Y \leq j \mid X_{i}\right)=36,878+10,809 X_{1}+3,230 X_{2}+2,580 X_{3}+1,774 X_{4}+2,505$ $\mathrm{X}_{5}+1,795 \mathrm{X}_{6}$

2. Logit $P\left(Y \leq j \mid X_{i}\right)=63,878+10,809 X_{1}+3,230 X_{2}+2,580 X_{3}+1,774 X_{4}+2,505$ $\mathrm{X}_{5}+1,795 \mathrm{X}_{6}$

As for the factors that significantly influence the selection of mathematics study programs obtained from the results of the partial parameter test are educational facilities of 6,250 and interest in talents of 3,870 > $\chi^{2}$ tabel $=3,841$ which means that there are one or more variables that have a significant effect. Overall, the independent variables affect the assessment of student satisfaction with the choice of mathematics study program at UINSA Surabaya by $94.8 \%$ and $5.2 \%$ influenced by other factors.

Keywords:

Cumulative Logit Model, Factors that Influence the Selection of Study Programs, Ordinal Logistic Regression.

\section{A. Pendahuluan}

Pendidikan merupakan sarana untuk mencari pengetahuan yang luas serta membangun masa depan cerah suatu bangsa dan negara. Pendidikan juga memiliki tingkatan-tingkatan berdasarkan kemampuan yang dimiliki oleh setia manusia dari mulai pendidikan dasar sampai pada pendidikan yang lebih tinggi (Wiliana, 2018). Lembaga perguruan tinggi juga sangat dibutuhkan oleh seseorang untuk meningkatkan satu bidang konsentrasi saat memasuki dunia kerja. Pemerintah juga berupaya untuk meningkatkan mutu pada perguruan tinggi melalui Sistem Penjaminan Mutu Perguruan Tinggi (SPMPT) (Mulyatini, Suharyati \& Handayani, 2013). Perguruan tinggi merupakan suatu lembaga pendidikan jenjang akhir yang mampu menciptakan mahasiswa memiliki nilai tambah, mendorong mahasiswa untuk mengembangkan kemampuan akademik maupun non akademik dan dapat menghasilkan suatu karya ilmiah serta inovasi teknologi. Banyak program pendidikan yang ditawarkan di perguruan tinggi negeri maupun swasta untuk menarik minat calon mahasiswa seperti peningkatan pelayanan, perbaikan sarana dan prasarana, dan lain sebagainya (Syardiansah, 2017). Memilih program studi di perguruan tinggi bukanlah hal yang mudah, ada beberapa faktor yang perlu dipertimbangkan sesuai dengan kemampuan yang dimiliki (Nalim, 2012).

Seringkali mahasiswa tergesa-gesa dalam memilih program studi yang berakibat pada mahasiswa merasa tidak sesuai dengan program pendidikan yang telah diambil disebabkan karena beberapa faktor diantaranya karena faktor ekonomi, merasa tidak sesuai dengan passion yang dimiliki, mata kuliah yang sulit dipahami, membayar uang kuliah dengan biaya sendiri dari hasil kerja kerasnya, kondisi fisik yang kurang baik, dan lain sebagainya (Risnawati \& Irwandi, 2012). Terdapat beberapa penelitian yang berkaitan dengan regresi logistik ordinal diantaranya yang dilakukan oleh Bahtiar dkk (2018) mengenai analisis pengaruh penggunaan laptop terhadap kesehatan mahasiswa fmipa universitas islam indonesia dengan regresi logistik ordinal dan diperoleh hasil bahwa faktor yang berpengaruh secara signifikan adalah asal program studi, 
Fadillahtur Rizka Nur Rian \& Moch. Hafiyusholeh: Analisis Faktor-Faktor yang Mempengaruhi Tingkat Kepuasan Mahasiswa Terhadap Pemilihan Program Studi Matematika UINSA Surabaya Menggunakan Metode Regresi Logistik Ordinal

ukuran laptop yang digunakan, durasi penggunaan laptop, perilaku saat menggunakan laptop, jenis keluhan. Secara keseluruhan variabel indepeden mempengaruhi penilaian terhadap kesehatan mahasiswa sebesar 65,9\%. Selanjutnya pada penelitian Ayu (2019) mengenai analisis regresi logistik ordinal untuk mengetahui faktor-faktor yang mempengaruhi hasil produksi mie soun di Kabupaten Klaten. Penelitian tersebut diperoleh hasil bahwa faktor yang berpengaruh secara signifikan adalah kualitas bahan dan tenaga kerja. Secara keseluruhan variabel independen mempengaruhi penilaian terhadap hasil produksi mie soun di kabupaten Klaten sebesar $78,7 \%$. Oleh karena itu perlu dilakukan penelitian mengenai faktor-faktor apa saja yang mempengaruhi tingkat kepuasan mahasiswa terhadap pemilihan program studi matematika UIN Sunan Ampel Surabaya. Terdapat beberapa metode yang digunakan untuk melihat faktor-faktor yang mempengaruhi tingkat kepuasan salah satunya regresi logistik ordinal. Metode yang dapat digunakan untuk melihat tingkat kepuasan mahasiswa terhadap pilihan program studi yang diambil adalah regresi logistik ordinal. Regresi logistik ordinal merupakan salah satu analisis yang digunakan untuk mengetahui lebih lanjut hubungan antara kepuasan mahasiswa terhadap pemilihan program studi matematika.

\section{B. Kajian Teoritis}

\section{Faktor-faktor yang Mempengaruhi Tingkat Kepuasan Mahasiswa terhadap Pemilihan Program Studi}

\section{a. Citra Program Studi}

Citra program studi merupakan suatu gambaran mengenai mengenai lingkungan sebagai hasil dari sebuah pengalaman. Citra program studi yang dimaksud dalam penelitian adalah citra dari instansi pendidikan tinggi. Jika program studi mempunyai citra yang baik, maka dimata masyarakat akan berfikiran bahwa program studi tersebut mempunyai kualitas yang baik. Citra yang baik tersebut akan mengembangkan kreativitas dan mampu memberikan manfaat bagi orang lain. Citra juga merupakan aset yang memiliki dampak pada persepsi mahasiswa dan operasi organisasi dalam berbagai hal.

\section{b. Fasilitas Pendidikan}

Fasilitas pendidikan merupakan sesuatu yang dapat memperlancar semua kegiatan yang dilakukan. Fasilitas tersebut dibagi menjadi 2 katagori yaitu sarana dan prasarana. Sarana merupakan fasilitas yang dapat langsung digunakan untuk proses pembelajaran diantaranya peralatan media pembelajaran. Prasarana merupakan fasilitas yang tidak dapat langsung digunakan untuk sistem pembelajaran diantaranya gedung, ruang ibadah, lapangan olahraga, halaman, akses jalan dll. Jika fasilitas pendidikan tersebut tersedia dengan lengkap dan dapat digunakan bagaimana fungsinya dalam proses pendidikan, maka mahasiswa akan merasa nyaman dalam melakukan semua aktivitas pembelajaran. Kelengkapan fasilitas pendidikan akan berpengaruh pada daya tarik serta aspek pertimbangan pada mahasiswa dalam menempuh program studi tersebut.

\section{c. Minat dan Bakat}

Minat merupakan suatu ketertarikan atau kondisi yang dimiliki oleh setiap individu yang ditanamkan sejak dini. Minat juga dapat mendorong seseorang untuk melakukan apa yang mereka inginkan (Maharani, Permanasari \& Rohayati, 2018). Suatu minat akan ditunjukkan bahwa seseorang tersebut lebih menyukai sesuatu hal yang mereka inginkan daripada hal yang lainnya. Jika minat seseorang tinggi, maka akan menghasilkan prestasi yang lebih tinggi, dan jika minat seseorang itu rendah, maka akan menghasilkan prestasi yang rendah juga. Seseorang yang memiliki minat terhadap sesuatu yang diingingkannya, maka seseorang tersebut selalu berjuang untuk mendapatkan hasil yang maksimal. Minat tersebut akan menjadi sebuah modal yang besar untuk mendapatkan sesuatu dan tujuan yang diamati. Minat juga akan memberikan perhatian yang sangat besar terhadap sesuatu. 
Bakat merupakan kemampuan seseorang untuk mengembangkan suatu potensi dan melatih diri. Bakat dapat berpengaruh besar dalam proses pembelajaran. Apabila seseorang menempuh pendidikan sesuai dengan bakat, maka akan berpengaruh pada keberhasilan seseorang tersebut. Adapun juga yang menjadi faktor penghambat adalah orang tua yang selalu memaksakan kehendak anaknya untuk mendaftarkan sekolah tanpa mengetahui bakat yang dimiliki oleh seorang anak. Memaksakan kehendak akan berpengaruh buruk pada prestasi belajar.

\section{d. Biaya Pendidikan}

Biaya pendidikan merupakan biaya pengeluaran yang berkaitan dengan penyelenggaraan pendidikan. Seluruh biaya pendidikan yang dikeluarkan bertujuan untuk keperluan mahasiswa mulai awal pendidikan sampai dengan berakhirnya pendidikan. Biaya pendidikan dapat meliputi biaya gedung, biaya per semester, dan biaya yang lainnya. Perguruan tinggi tersebut telah menetapkan biaya pendidikan berdasarkan pogram studi yang diambil, penghasilan orang tua, tingkat mahasiswa, jenis program mahasiswa, dan beban kredit mahasiswa.

\section{e. Prospek Program Studi}

Prospek merupakan kemungkinan atau harapan. Prospek program studi merupakan tersedianya peluang kerja bagi lulusan yang akan menghasilkan suatu barang atau jasa. Di dalam prospek program studi akan terdapat prospek kerja bagi mahasiswa. Pada prospek kerja akan menjadi daya tarik tersendiri dalam memilih program studi yang akan diambil oleh mahasiswa. Jika pada program studi memiliki prospek kerja yang baik akan dapat menarik minat mahasiswa dalam memilih program studi tersebut dan jika pada program studi tersebut memiliki prospek kerja yang kurang maka mahasiswa akan berfikir kembali. Prospek kerja yang tinggi akan menjadi pertimbangan bagi mahasiswa untuk memilih program studi.

\section{f. Faktor Sosial}

Faktor sosial merupakan suatu tindakan yang dapat mempengaruhi perilaku seseorang berdasarkan kebiasaan yang dilakukan. Faktor sosial tersebut terdiri dari kelompok referensi,keluarga, peran dan status (Martini, 2013). Kelompok referensi merupakan interaksi yang saling bergantung antara dua individu atau lebih untuk mendapatkan suatu tujuan tertentu dan memiliki pengaruh langsung maupun tidak langsung terhadap sikap dan perilaku seseorang. Kelompok referensi juga dipengaruhi oleh kelompok-kelompok kecil yaitu kelompok primer yang terdiri dari keluarga, teman, tetangga dan kelompok sekunder yang terdiri dari dari organisasi, majelis, asosiasi profesional serta serikat buruh. Keluarga merupakan ikatan yang dikaitkan dengan hubungan darah dan tinggal bersama. Keluarga juga memiliki pengaruh yang sangat besar terhadap perilaku seseorang. Status merupakan posisi atau tingkatan yang telah ditentukan secara sosial dan dimiliki oleh setiap orang. Peran juga akan membawa status yang dapat menggambarkan penghargaan yang diberikan oleh seseorang.

\section{Regresi Logistik Ordinal}

Regresi logistik ordinal merupakan sebuah metode yang digunakan untuk mengetahui hubungan terhadap variabel terikat atau respon (dependen) yang berbentuk skala ordinal dengan variabel bebas (independen). Regresi logistik ordinal juga merupakan perluasan dari regresi logistik biner. Di bawah ini adalah bentuk spesifik dari regresi logistik (Puspasari, 2017):

dimana $f(z)=\alpha+\beta_{1} X_{1}+\beta_{2} X_{2}+\beta_{3} X_{3}+\ldots+\beta_{i} X_{i k}$

$$
g(x)=\frac{e^{f(z)}}{1+e^{f(z)}}
$$

Sehingga

$$
g(x)=\frac{e^{\alpha+\beta_{1} X_{1}+\beta_{2} X_{2}+\beta_{3} X_{3}+\ldots+\beta_{i} X_{i k}}}{1+e^{\alpha+\beta_{1} X_{1}+\beta_{2} X_{2}+\beta_{3} X_{3}+\ldots+\beta_{i} X_{i k}}}
$$


Fadillahtur Rizka Nur Rian \& Moch. Hafiyusholeh: Analisis Faktor-Faktor yang Mempengaruhi Tingkat Kepuasan Mahasiswa Terhadap Pemilihan Program Studi Matematika UINSA Surabaya Menggunakan Metode Regresi Logistik Ordinal

Model yang digunakan dalam regresi logistik ordinal adalah model logit kumulatif. Model logit kumulatif merupakan model yang memiliki sifat ordinal dari variabel terikat $\mathrm{Y}$ dalam peluang kumulatif, sehingga model yang diperoleh dengan cara membandingkan peluang kumulatif yaitu peluang $\mathrm{Y}$ kurang dari sama dengan katagori respon ke-j pada $\mathrm{k}$ variabel independen yang dinyatakan oleh $\mathrm{X}_{\mathrm{i}}(\mathrm{P}(\mathrm{Y} \leq \mathrm{j} \mid \mathrm{Xi}))$ dengan peluang $\mathrm{Y}$ lebih dari katagori respon ke-j pada variabel terikat $\mathrm{Y}(\mathrm{P}(\mathrm{Y}>\mathrm{j} \mid \mathrm{Xi}))$. Maka peluang kumulatif dapat didefinisikan sebagaimana yang dinyatakan oleh (Al-Fattah, 2014) yaitu:

$$
P\left(Y \leq j \mid X_{i}\right)=g(x)=\frac{e^{\alpha+\beta_{1} X_{1}+\beta_{2} X_{2}+\beta_{3} X_{3}+\ldots+\beta_{i} x_{i k}}}{1+e^{\alpha+\beta_{1} X_{1}+\beta_{2} X_{2}+\beta_{3} X_{3}+\ldots+\beta_{i} X_{i k}}}
$$

Jika terdapat $\mathrm{j}$ merupakan jumlah kategori respon pada variabel dependen dimana $\mathrm{j}=1,2,3$ maka nilai peluang untuk masing-masing kategori adalah (Salamah, 2015):

$$
\begin{aligned}
& \pi_{1}\left(\mathrm{X}_{\mathrm{i}}\right)=\mathrm{P}\left(\mathrm{Y}=1 \mid \mathrm{X}_{\mathrm{i}}\right) \\
& =\mathrm{P}\left(\mathrm{Y} \leq 1 \mid \mathrm{X}_{\mathrm{i}}\right) \\
& =\frac{\mathrm{e}^{\alpha_{1}+\beta_{1} \mathrm{X}_{1}+\beta_{2} \mathrm{X}_{2}+\beta_{3} \mathrm{X}_{3}+\ldots+\beta_{\mathrm{i}} \mathrm{X}_{\mathrm{ik}}}}{1+\mathrm{e}^{\alpha_{1}+\beta_{1} \mathrm{X}_{1}+\beta_{2} \mathrm{X}_{2}+\beta_{3} \mathrm{X}_{3}+\ldots+\beta_{\mathrm{i}} \mathrm{X}_{\mathrm{ik}}}} \\
& \pi_{2}\left(\mathrm{X}_{\mathrm{i}}\right)=\mathrm{P}\left(\mathrm{Y}=2 \mid \mathrm{X}_{\mathrm{i}}\right) \\
& =\mathrm{P}\left(\mathrm{Y} \leq 2 \mid \mathrm{X}_{\mathrm{i}}\right)-\mathrm{P}\left(\mathrm{Y} \leq 1 \mid \mathrm{X}_{\mathrm{i}}\right)
\end{aligned}
$$

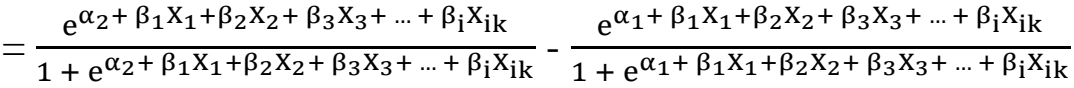

$$
\begin{aligned}
& \pi_{3}\left(\mathrm{X}_{\mathrm{i}}\right)=\mathrm{P}\left(\mathrm{Y}=3 \mid \mathrm{X}_{\mathrm{i}}\right) \\
& =\mathrm{P}\left(\mathrm{Y} \leq 3 \mid \mathrm{X}_{\mathrm{i}}\right)-\mathrm{P}\left(\mathrm{Y} \leq 2 \mid \mathrm{X}_{\mathrm{i}}\right) \\
& =1-\frac{\mathrm{e}^{\alpha_{2}+\beta_{1} \mathrm{X}_{1}+\beta_{2} \mathrm{X}_{2}+\beta_{3} \mathrm{X}_{3}+\ldots+\beta_{\mathrm{i}} \mathrm{x}_{\mathrm{ik}}}}{1+\mathrm{e}^{\alpha_{2}+\beta_{1} \mathrm{X}_{1}+\beta_{2} \mathrm{X}_{2}+\beta_{3} \mathrm{X}_{3}+\ldots+\beta_{\mathrm{i}} \mathrm{X}_{\mathrm{ik}}}}
\end{aligned}
$$

\section{Estimasi Parameter}

Terdapat beberapa pendekatan yang digunakan untuk mendapatkan nilai estimasi parameter $\alpha$ dan $\beta$. Metode yang digunakan dalam estimasi parameter adalah Maximum Likelihood Estimation (MLE). Untuk melakukan metode MLE, pertama yang dilakukan adalah mendefinisikan fungsi likelihood $1(\beta)$, dimana $\beta$ merupakan parameter yang belum diketahui. Persamaan dari fungsi likelihood $1(\beta)$ sebagaimana yang dinyatakan oleh (Angreni, 2017) $a^{\text {dalah }}$

Dengan $\mathrm{i}=1,2,3, \ldots$ nan $\mathrm{j}=1,2,3$

$$
1(\beta)=\prod_{i=1}^{n} \pi_{1}\left(X_{i}\right)^{y_{1 i}} \pi_{2}\left(X_{i}\right)^{y_{2 i}} \pi_{3}\left(X_{i}\right)^{y_{3 i}}
$$

Dari persamaan (2) maka diperoleh fungsi ln-likelihood adalah sebagai berikut:

$$
1(\beta)=\sum_{i=n}^{n} y_{1 i} \ln \left[\pi_{1}\left(\mathrm{X}_{\mathrm{i}}\right)\right]+y_{2 i} \ln \left[\pi_{2}\left(\mathrm{X}_{\mathrm{i}}\right)\right]+y_{3 i} \ln \left[\pi_{3}\left(\mathrm{X}_{\mathrm{i}}\right)\right]
$$

Maksimum Likelihood dapat diperoleh dengan cara mendiferensialkan atau menurunkan logaritma natural dari fungsi $1(\beta)$ terhadap parameter yang akan diestimasi dan disamakan dengan nol. Hasil dari diferensial tersebut merupakan fungsi nonlinier yang sulit untuk diselesaikan secara manual. Oleh karena itu untuk membantu perhitungan estimasi parameter digunakan iterasi fisher scoring atau newton-raphson dengan menggunakan program komputer.

\section{Uji Kesesuaian Model (Goodness of Fit Test)}

Uji Kesesuaian Model (Goodness of Fit Test) merupakan suatu uji yang digunakan untuk mengetahui apakah model tersebut sesuai atau tidak. Nilai dalam uji kesesuaian model berkisar antara 0 sampai 1. Uji Kesesuaian Model (Goodness of Fit Test) menggunakan uji deviance. Persamaan dalam Uji Deviance adalah (Zakariyah \& Zain, 2015):

Pengujian Hipotesis:

$$
\mathrm{D}=-2 \sum_{i=1}^{n}\left[y_{i} \ln \left(\frac{\pi}{y_{i}}\right)+\left(1-y_{i}\right) \ln \left(\frac{1-\pi_{i}}{1-y_{i}}\right)\right]
$$

$\mathrm{H}_{0}=$ Model dinyatakan sesuai Jika nilai (D) $<\mathrm{X}_{(\alpha, \mathrm{df})}^{2}$ atau $\mathrm{sig}>\alpha(0,05)$

$\mathrm{H}_{1}=$ Model dinyatakan tidak sesuai (D) $>\mathrm{X}_{(\alpha, \mathrm{df})}^{2}$ atau nilai sig $<\alpha(0,05)$ 


\section{Pengujian Parameter}

Pengujian parameter dalam regresi logistik ordinal digunakan untuk mengetahui pengaruh antara variabel bebas terhadap variabel respon. Pengujian parameter yang dilakukan terdiri dari 2 yaitu uji serentak dan uji parsial (Budyanra \& Azzahra, 2015). Pada uji serentak tersebut dilakukan dengan cara uji Likelihood Ratio Test (G). Uji statistik Likelihood Ratio Test (G) digunakan untuk memeriksa peranan pada variabel bebas secara serentak. Persamaan dalam uji statistik Likelihood Ratio Test (G) adalah :

Pengujian Hipotesis

$$
\mathrm{G}=-2 \log \left(\frac{l_{0}}{l_{1}}\right)=-2\left[\log \left(l_{0}\right)-\log \left(l_{1}\right)\right]=-2\left(l_{0}-l_{1}\right)
$$

$\mathrm{H}_{0}: \beta_{1}=\beta_{2}=\ldots=\beta \mathrm{k}=0$

$\mathrm{H}_{1}$ : Minimum terdapat satu atau lebih $\beta_{\mathrm{i}} \neq 0$ dengan $\mathrm{i}=1,2,3, \ldots \mathrm{k}$

Kemudian pada uji parsial tersebut dilakukan dengan cara uji statistik Wald (W). Uji statistik Wald (W) digunakan untuk memeriksa peranan pada variabel bebas secara parsial. Persamaan dalam uji statistik Wald (W) adalah

Pengujian Hipotesis

$$
\mathrm{W}^{2}=\left(\frac{\beta_{i}}{S E\left(\beta_{i}\right)}\right)^{2}
$$

$\mathrm{H}_{0}: \beta_{i}=0$

$\mathrm{H}_{1}: \beta_{i} \neq 0, \mathrm{i}=1,2,3, \ldots, \mathrm{n}$

\section{Uji Koefisien Determinasi Model}

Koefisien determinasi model $\left(\mathrm{R}^{2}\right)$ merupakan uji yang digunakan untuk mengetahui seberapa besar variabel bebas (Independen) dapat mempengaruhi varibel terikat (Dependen). Nilai pada koefisien determinasi model $\left(\mathrm{R}^{2}\right)$ berkisar antara 0 sampai dengan 1 . Dalam koefisien determinasi model $\left(\mathrm{R}^{2}\right)$ dapat menggunakan uji sebagai berikut (Albana, 2013):

a. Cox and Snell

$$
\mathrm{R}_{\mathrm{CS}}^{2}=1-e^{\left(\frac{2}{n}(\text { likelihood model B }- \text { likelihood model } A)\right)}
$$

b. Negelkerke

$$
\mathrm{R}^{2}{ }_{\mathrm{N}}=\frac{R^{2} \text { CS }}{1-e^{\left(\frac{2}{n}(\text { likelihoodmodelA })\right)}}
$$

c. Mc Fadden

$$
\mathrm{R}^{2} \text { Mc.Fadden }=1-\left(\frac{\text { Likelihood Model B }}{\text { Likelihood Model A }}\right)
$$

\section{Metode Penelitian}

Penelitian ini menggunakan data primer yang diperoleh dengan menyebarkan kuisioner atau angket kepada mahasiswa yang memilih program studi matematika UINSA Surabaya angkatan 2016 s.d 2019 sebanyak 100 mahasiswa. Variabel merupakan suatu parameter yang digunakan sebagai objek penelitian sehingga akan menghasilkan sebuah informasi dan dapat ditarik kesimpulannya. Ada 6 variabel bebas (independen) yang meliputi citra program studi, fasilitas pendidikan, minat dan bakat, biaya pendidikan, prospek program studi, serta faktor sosial dan 1 variabel terikat (dependen) yaitu kepuasan mahasiswa terhadap pemilihan program studi matematika UIN Sunan Ampel Surabaya.

Adapun langkah-langkah dalam penelitian mengenai analisis faktor-faktor yang mempengaruhi tingkat kepuasan mahasiswa terhadap pemilihan program studi matematika UIN Sunan Ampel Surabaya menggunakan metode regresi logistik ordinal sebagai berikut:

1. Melakukan studi pendahuluan mengenai faktor-faktor yang mempengaruhi tingkat kepuasan terhadap pemilihan program studi matematika UIN Sunan Ampel Surabaya.

2. Pengumpulan instrument dan pembuatan kuisioner yang disebarkan kepada mahasiswa program studi matematika angkatan tahun 2016 s.d. 2019.

3. Kuisioner akan divalidasi oleh validator ahli.

4. Penyebaran kuisioner kepada 100 mahasiswa program studi matematika. 
Fadillahtur Rizka Nur Rian \& Moch. Hafiyusholeh: Analisis Faktor-Faktor yang Mempengaruhi Tingkat Kepuasan Mahasiswa Terhadap Pemilihan Program Studi Matematika UINSA Surabaya Menggunakan Metode Regresi Logistik Ordinal

5. Melakukan uji validitas dan reliabilitas kepada 30 responden mahasiswa program studi matematika UIN SunanAmpel Surabaya.

6. Melakukan Uji Multikolinearitas

7. Analisis data menggunakan Regresi Logistik Ordinal

a. Melakukan Pembentukan model logit kumulatif

b. Melakukan uji kesesuaian model (Goodness of Fit Test) menggunakan uji deviance

c. Melakukan pengujian parameter serentak dan parsial

d. Melakukan uji koefisien determinasi model

D. Hasil Penelitian dan Pembahasan

\section{Uji Validitas}

Uji Validitas merupakan teknik yang digunakan untuk menguji validitas pada butir pernyataan dalam kuisioner. Berikut hasil dari uji validitas terhadap 30 responden menggunakan program SPSS:

Tabel 1. Hasil Uji Validitas

\begin{tabular}{|c|c|c|c|c|c|}
\hline No. & Nama Variabel & $\begin{array}{c}\text { No. Item } \\
\text { Pernyataan }\end{array}$ & $\mathbf{R}_{\text {Hitung }}$ & $\mathbf{R}_{\text {Tabel }}$ & Keterangan \\
\hline \multirow[t]{5}{*}{1.} & Citra Program Studi & $\mathrm{X}_{1,1}$ & 0,912 & 0,3610 & Valid \\
\hline & & $\mathrm{X}_{1,2}$ & 0,914 & & \\
\hline & & $\mathrm{X}_{1,3}$ & 0,900 & & \\
\hline & & $\mathrm{X}_{1,4}$ & 0,508 & & \\
\hline & & $\mathrm{X}_{1,5}$ & 0,439 & & \\
\hline \multirow[t]{5}{*}{2.} & Fasilitas Pendidikan & $\mathrm{X}_{2,1}$ & 0,778 & 0,3610 & Valid \\
\hline & & $X_{2,2}$ & 0,666 & & \\
\hline & & $\mathrm{X}_{2,3}$ & 0,594 & & \\
\hline & & $\mathrm{X}_{2,4}$ & 0,712 & & \\
\hline & & $X_{2,5}$ & 0,727 & & \\
\hline \multirow[t]{4}{*}{3.} & Minat dan bakat & $X_{3,1}$ & 0,797 & 0,3610 & Valid \\
\hline & & $X_{3,2}$ & 0,764 & & \\
\hline & & $\mathrm{X}_{3,3}$ & 0,852 & & \\
\hline & & $X_{3,4}$ & 0,397 & & \\
\hline \multirow[t]{2}{*}{4.} & Biaya Pendidikan & $\mathrm{X}_{4,1}$ & 0,891 & 0,3610 & Valid \\
\hline & & $\mathrm{X}_{4,2}$ & 0,888 & & \\
\hline \multirow[t]{4}{*}{5.} & Prospek Program Studi & $\mathrm{X}_{5,1}$ & 0,624 & 0,3610 & Valid \\
\hline & & $\mathrm{X}_{5,2}$ & 0,560 & & \\
\hline & & $\mathrm{X}_{5,3}$ & 0,660 & & \\
\hline & & $\mathrm{X}_{5,4}$ & 0,510 & & \\
\hline \multirow[t]{6}{*}{6.} & Faktor Sosial & $X_{6,1}$ & 0,759 & 0,3610 & Valid \\
\hline & & $X_{6,2}$ & 0,462 & & \\
\hline & & $\mathrm{X}_{6,3}$ & 0,706 & & \\
\hline & & $\mathrm{X}_{6,4}$ & 0,744 & & \\
\hline & & $X_{6,5}$ & 0,476 & & \\
\hline & & $X_{6,6}$ & 0,484 & & \\
\hline
\end{tabular}

Dilihat dari tabel diatas dapat disimpulkan bahwa semua item butir pernyataan dengan $r_{\text {hitung }}>$ $r_{\text {tabel }}=0,3610$ sehingga tolak $\mathrm{H}_{0}$ dan terima $\mathrm{H}_{1}$ artinya pernyataan dalam kuisioner dinyatakan valid. 


\section{Uji Reliabilitas}

Uji Reliabilitas digunakan untuk menguji sebuah hasil pengukuran melalui kuisioner yang konsisten dalam perulangan pengukuran yang berbeda sehingga dapat mengetahui tingkat kesalahan pengukuran. Berikut hasil dari uji reliabilitas terhadap 30 responden menggunakan program SPSS:

Tabel 2. Hasil Uji Reliabilitas

\begin{tabular}{cccc}
\hline No. & Nama Variabel & Nilai Cronbach Alpha & Keterangan \\
\hline 1. & Citra Program Studi & 0,795 & Reliabel \\
2. & Fasilitas Pendidikan & 0,775 & Reliabel \\
3. & Minat dan Bakat & 0,780 & Reliabel \\
4. & Biaya Pendidikan & 0,888 & Reliabel \\
5. & Prospek Program Studi & 0,711 & Reliabel \\
6. & Faktor Sosial & 0,736 & Reliabel \\
\hline
\end{tabular}

Dilihat dari tabel diatas dapat disimpulkan bahwa nilai dari uji reliabilitas semua variabel bebas lebih dari lebih dari 0,60 maka pengambilan keputusan adalah tolak $\mathrm{H}_{0}$ dan terima $\mathrm{H}_{1}$ artinya pernyataan dalam kuisioner dinyatakan reliabel.

\section{Penentuan Skoring pada Tingkat Kepuasan Mahasiswa}

Hasil penyebaran kuisioner yang sudah disebarkan sejumlah 100 kuisioner yang mewakili mahasiswa program studi matematika UINSA Surabaya. Untukmengetahui tingkat kepuasan mahasiswa terhadap pemilihan program studi tersebut menggunakan penentuan skoring kriteria. Dibawah ini adalah perhitungan dari penentuan skoring:

Jumlah pilihan jawaban adalah 5 kriteria

Jumlah Pernyataan adalah 26 pernyataan

Jumlah Skor Terendah adalah 1 x $26=26\left(\frac{26}{130} \times 100 \%\right)=20 \%$

Jumlah Skor Tertinggi adalah 5 x $26=130\left(\frac{130}{130} \times 100 \%\right)=100 \%$

Range $(\mathrm{R})=$ Skor Tertinggi - Skor Terendah $=100 \%-20 \%=80 \%$

Jumlah Kriteria yang disusun adalah 3 kriteria

Interval $=\frac{\text { Range }}{\text { Kriteria }}=\frac{80 \%}{3}=26,67 \%$

Pengklasifikasian kriteria sebagai berikut

a. Sesuai $=$ jika skor total $>(100 \%-26,67 \%)=73,33 \%$

b. Cukup = jika $26,67 \%<$ skor total $\leq 73,33 \%$

c. Tidak Sesuai $=$ jika skor total $\leq 26,67 \%$

\section{Uji Multikolineritas}

Uji Multikolinearitas merupakan uji yang digunakan untuk melihat hubungan korelasi antar variabel bebas. Sebuah model regresi yang bagus tidak akan terjadi suatu hubungan atau korelasi yang linier antar variabel bebas (Independent) yang disebut dengan multikolinearitas. Berikut hasil dari uji multikolinearitas menggunakan program SPSS:

Tabel 3. Hasil Uji Multikolinearitas

\begin{tabular}{cccc}
\hline No. & Nama Variabel & Nilai VIF & Nilai Toleransi \\
\hline 1. & Citra Program Studi & 1,313 & 0,762 \\
2. & Fasilitas Pendidikan & 1,176 & 0,850 \\
3. & Minat dan Bakat & 1,122 & 0,891 \\
4. & Biaya Pendidikan & 1,414 & 0,707 \\
5. & Prospek Program Studi & 1,207 & 0,829 \\
6. & Faktor Sosial & 1,243 & 0,804 \\
\hline
\end{tabular}


Fadillahtur Rizka Nur Rian \& Moch. Hafiyusholeh: Analisis Faktor-Faktor yang Mempengaruhi Tingkat Kepuasan Mahasiswa Terhadap Pemilihan Program Studi Matematika UINSA Surabaya Menggunakan Metode Regresi Logistik Ordinal

Dari hasil diatas dapat disimpulkan bahwa semua variabel bebas tersebutmemiliki nilai VIF $\leq 10$ dengan nilai toleransi $>0,10$ artinya tidak terjadi adanya hubungan korelasi antar variabel bebas yang disebut dengan Multikolinearitas.

\section{Pembentukan Model Regresi Logistik Ordinal}

Analisis data yang digunakan pada penelitian ini menggunakan analisis regresi logistik ordinal. Dibawah ini adalah output data yang diolah dengan menggunakan program SPSS:

\section{Tabel 4. Hasil Model Logit Kumulatif}

\section{Parameter Estimates}

\begin{tabular}{|c|c|c|c|c|c|c|c|c|}
\hline & \multirow[b]{2}{*}{ Estimate } & \multirow[b]{2}{*}{$\begin{array}{l}\text { Std. } \\
\text { Error }\end{array}$} & \multirow[b]{2}{*}{ Wald } & \multirow[b]{2}{*}{ Df } & \multirow[b]{2}{*}{ Sig. } & \multicolumn{2}{|c|}{$\begin{array}{c}\text { 95\% Confidence } \\
\text { Interval } \\
\end{array}$} \\
\hline & & & & & & & $\begin{array}{l}\text { Lower } \\
\text { Bound }\end{array}$ & $\begin{array}{l}\text { Upper } \\
\text { Bound }\end{array}$ \\
\hline \multirow[t]{2}{*}{$\begin{array}{l}\text { Threshol } \\
\text { d }\end{array}$} & {$[\mathrm{Y}=1]$} & 36.878 & 332.721 & .012 & 1 & .912 & 615.243 & 688.999 \\
\hline & {$[\mathrm{Y}=2]$} & 63.018 & 499.100 & .016 & 1 & .900 & 915.200 & $\begin{array}{r}1041.23 \\
5\end{array}$ \\
\hline \multirow[t]{6}{*}{ Location } & Citra_Program_Studi & 10.809 & 166.346 & .004 & 1 & .948 & 315.224 & 336.841 \\
\hline & Fasilitas_Pendidikan & 3.230 & 1.292 & 6.250 & 1 & .012 & .698 & 5.762 \\
\hline & Minat_dan_Bakat & 2.580 & 1.311 & 3.870 & 1 & .049 & .010 & 5.150 \\
\hline & Biaya_Pendidikan & 1.774 & 1.227 & 2.090 & 1 & .148 & -.631 & 4.180 \\
\hline & $\begin{array}{l}\text { Prospek_Program_St } \\
\text { udi }\end{array}$ & 2.505 & 1.281 & 3.827 & 1 & .050 & -.005 & 5.015 \\
\hline & Sosial & 1.795 & 1.412 & 1.616 & 1 & .204 & -.973 & 4.563 \\
\hline
\end{tabular}

Dari hasil diatasdapat disimpulkan bahwa nilai variabel konstanta pada kolom estimate dan baris threshold masing-masing sebesar 36,878 dan 63,018. Sedangkan untuk nilai koefisien $\beta$ masingmasing sebesar 10,809, 3,230, 2,580, 1,744, 2,505, 1,795 sehingga dapat dibentuk 3 interval untuk menentukan kategori kepuasan mahasiswa terhadap pemilihan Program Studi Matematika UINSA Surabaya yaitu :

1. Kategori Tidak Sesuai $(Y=1)$ jika $y^{*} \leq 36,878$

2. Kategaori Cukup $(Y=2)$ jika $36,878<y^{*} \leq 63,018$

3. Kategori Sesuai $(Y=3)$ jika $y^{*}>63,018$

Dimana $y^{*}=10,809 X_{1}+3,230 X_{2}+2,580 X_{3}+1,774 X_{4}+2,505 X_{5}+1,795 X_{6}$. Dihasilkan persamaan model logit kumulatif sebagai berikut dari tabel estimasi parameter:

1. Logit $P\left(Y \leq j \mid X_{i}\right)=36,878+10,809 X_{1}+3,230 X_{2}+2,580 X_{3}+1,774 X_{4}+2,505 X_{5}+$ $1,795 \mathrm{X}_{6}$

2. Logit $P\left(Y \leq j \mid X_{i}\right)=63,878+10,809 X_{1}+3,230 X_{2}+2,580 X_{3}+1,774 X_{4}+2,505 X_{5}+$ $1,795 \mathrm{X}_{6}$

Dari model logit diatas maka peluang tingkat kepuasan mahasiswa terhadap pemilihan program studi matematika UIN SunanAmpel Surabaya pada masing-masing kategori adalah :

$$
\begin{aligned}
\pi_{1}\left(\mathrm{X}_{\mathrm{i}}\right) & =\mathrm{P}\left(\mathrm{Y}=1 \mid \mathrm{X}_{\mathrm{i}}\right) \\
& =\mathrm{P}\left(\mathrm{Y} \leq 1 \mid \mathrm{X}_{\mathrm{i}}\right) \\
& =\frac{\mathrm{e}^{36,878+10,809 \mathrm{X}_{1}+3,230 \mathrm{X} 2+2,580 \mathrm{X} 3+1,774 \mathrm{X} 4+2,505 \times 5+1,795 \mathrm{X} 6}}{1+\mathrm{e}^{36,878+10,809 \mathrm{X}_{1}+3,230 \mathrm{X} 2+2,580 \times 3+1,774 \mathrm{X} 4+2,505 \mathrm{X} 5+1,795 \times 6}} \\
& =0,768 \\
\pi_{2}\left(\mathrm{X}_{\mathrm{i}}\right) & =\mathrm{P}\left(\mathrm{Y}=2 \mid \mathrm{X}_{\mathrm{i}}\right) \\
& =\mathrm{P}\left(\mathrm{Y} \leq 2 \mid \mathrm{X}_{\mathrm{i}}\right)-\mathrm{P}\left(\mathrm{Y} \leq 1 \mid \mathrm{X}_{\mathrm{i}}\right)
\end{aligned}
$$




$$
\begin{aligned}
& =\frac{\mathrm{e}^{63,878+10,809 \mathrm{X}_{1}+3,230 \mathrm{X}_{2}+2,580 \mathrm{X}_{3}+1,774 \mathrm{X}_{4}+2,505 \mathrm{X}_{5}+1,795 \mathrm{X}_{6}}}{1+\mathrm{e}^{63,878+10,809 \mathrm{X}_{1}+3,230 \mathrm{X}_{2}+2,580 \mathrm{X}_{3}+1,774 \mathrm{X}_{4}+2,505 \mathrm{X}_{5}+1,795 \mathrm{X}_{6}}}-
\end{aligned}
$$

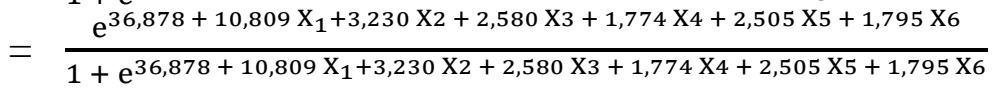

$$
\begin{aligned}
& =0,114 \\
& \pi_{2}\left(\mathrm{X}_{\mathrm{i}}\right)=\mathrm{P}\left(\mathrm{Y}=3 \mid \mathrm{X}_{\mathrm{i}}\right) \\
& =\mathrm{P}\left(\mathrm{Y} \leq 3 \mid \mathrm{X}_{\mathrm{i}}\right)-\mathrm{P}\left(\mathrm{Y} \leq 2 \mid \mathrm{X}_{\mathrm{i}}\right) \\
& =1-\frac{\mathrm{e}^{63,878+10,809 \mathrm{X}_{1}+3,230 \mathrm{X}_{2}+2,580 \mathrm{X}_{3}+1,774 \mathrm{X}_{4}+2,505 \mathrm{X}_{5}+1,795 \mathrm{X}_{6}}}{1+\mathrm{e}^{63,878+10,809 \mathrm{X}_{1}+3,230 \mathrm{X}_{2}+2,580 \mathrm{X}_{3}+1,774 \mathrm{X}_{4}+2,505 \mathrm{X}_{5}+1,795 \mathrm{X}_{6}}} \\
& =0,118
\end{aligned}
$$

\section{Uji Kesesuaian Model (Goodness of Fit Test)}

Uji kesesuaian model digunakan untuk mengetahui apakah model regresi logistik ordinal yang didapatkan sudah sesuai untuk digunakan. Berikut hasil dari uji kesesuaian model menggunakan program SPSS.

Tabel 5. Hasil Uji Kesesuaian Model (Goodness of Fit Test)

\begin{tabular}{lccc}
\hline \multicolumn{4}{c}{ Goodness-of-Fit } \\
\hline Chi-Square & Df & Sig. \\
\hline Pearson & 18.656 & 98 & 1.000 \\
Deviance & 12.294 & 98 & 1.000 \\
\hline
\end{tabular}

Dari hasil diatas dapat disimpulkan bahwa nilai uji Deviance sebesar 12,294 dan nilai signifikansi sebesar 1,000 dengan nilai $\mathrm{X}_{(0,05,98)}=122,10773$ karena nilai uji Deviance sebesar $12,294<$ nilai $\mathrm{X}_{(0,05,98)}^{2}=122,10773$ maka terima $\mathrm{H}_{0}$ dan tolak $\mathrm{H}_{1}$ artinya model dinyatakan sesuai.

\section{Pengujian Parameter}

\section{a. Uji Serentak}

Uji serentak digunakan untuk memeriksa peranan pada variabel bebas secara serentak. Uji serentak dialukan untuk membandingkan model tanpa variabel bebas dan model yang disertai dengan variabel bebas. Berikut hasil dari uji likelihood rasio test menggunakan program SPSS:

Tabel 6. Hasil Uji Serentak

\begin{tabular}{lcccc}
\hline \multicolumn{5}{c}{ Model Fitting Information } \\
\hline \multicolumn{1}{c}{ Model } & $\mathbf{- 2 ~ L o g ~ L i k e l i h o o d}$ & Chi-Square & Df & Sig. \\
\hline Intercept Only & 81.273 & & & \\
Final & .000 & 81.273 & 6 & .000 \\
\hline
\end{tabular}

Dari hasil diatas diketahui bahwa nilai dari -2 loglikelihood (intercept only/ tanpa variabel bebas) sebesar 81,273, -2 loglikelihood (final/ dengan variabel bebas) sebesar 0,000 serta nilai uji nilai Likelihood Ratio Test $(G)=81,273$. Dengan demikian nilai Uji Likelihood Ratio Test $(G)=$ $81,273>\mathrm{X}_{(0,05,6)}^{2}=12,59159$ maka tolak $\mathrm{H}_{0}$ dan terima $\mathrm{H}_{1}$ artinya terdapat salah satu atau lebih variabel bebas yang berpengaruh secara signifikan.

\section{b. Uji Parsial}

Uji Parsial digunakan untuk memeriksa peranan pada variabel bebas secara parsial. Berikut hasil dari uji wald menggunakan program SPSS:. 


\begin{tabular}{|c|c|c|c|c|c|c|c|c|}
\hline & & \multirow[b]{2}{*}{ Estimate } & \multirow[b]{2}{*}{$\begin{array}{l}\text { Std. } \\
\text { Error }\end{array}$} & \multirow[b]{2}{*}{ Wald } & \multirow[b]{2}{*}{ Df } & \multirow[b]{2}{*}{ Sig. } & \multicolumn{2}{|c|}{$\begin{array}{c}\text { 95\% Confidence } \\
\text { Interval } \\
\end{array}$} \\
\hline & & & & & & & $\begin{array}{l}\text { Lower } \\
\text { Bound }\end{array}$ & $\begin{array}{l}\text { Upper } \\
\text { Bound }\end{array}$ \\
\hline \multirow[t]{2}{*}{$\begin{array}{l}\text { Threshol } \\
\text { d }\end{array}$} & {$[\mathrm{Y}=1]$} & 36.878 & 332.721 & .012 & 1 & .912 & $615.243^{-}$ & 688.999 \\
\hline & {$[\mathrm{Y}=2]$} & 63.018 & 499.100 & .016 & 1 & .900 & $915.200^{-}$ & $\begin{array}{r}1041.23 \\
5\end{array}$ \\
\hline \multirow[t]{6}{*}{ Location } & Citra_Program_Studi & 10.809 & 166.346 & .004 & 1 & .948 & $315.224^{-}$ & 336.841 \\
\hline & Fasilitas_Pendidikan & 3.230 & 1.292 & 6.250 & 1 & .012 & .698 & 5.762 \\
\hline & Minat_dan_Bakat & 2.580 & 1.311 & 3.870 & 1 & .049 & .010 & 5.150 \\
\hline & Biaya_Pendidikan & 1.774 & 1.227 & 2.090 & 1 & .148 & -.631 & 4.180 \\
\hline & $\begin{array}{l}\text { Prospek_Program_St } \\
\text { udi }\end{array}$ & 2.505 & 1.281 & 3.827 & 1 & .050 & -.005 & 5.015 \\
\hline & Sosial & 1.795 & 1.412 & 1.616 & 1 & .204 & -.973 & 4.563 \\
\hline
\end{tabular}

Dari hasil diatas menunjukkan bahwa variabel bebas yang berpengaruh secara signifikan adalah fasilitas pendidikan, minat bakat dan prospek program studi. Sehingga didapatkan variabel yang signifikan terhadap model Regresi Logistik Ordinal yaitu fasilitas pendidikan, minat dan bakat, prospek program studi.

\section{Uji Koefisien Determinasi Model}

Besarnya nilai koefisien determinasi model ditunjukkan pada nilai cox and snell, nagelkerke, dan Mc.Fadden. Berikut hasil dari uji koefisen determinasi model menggunakan program SPSS:

Tabel 8. Hasil Uji Koefisien Determinasi Model

\begin{tabular}{lr} 
& Pseudo R-Square \\
\hline Cox and Snell & .556 \\
Nagelkerke & .948 \\
McFadden & .919 \\
\hline
\end{tabular}

Dilihat dari hasil diatas dapat disimpulkan bahwa nilai koefisien determinasi model $\left(\mathrm{R}^{2}\right)$ adalah pada uji Cox dan Snell sebesar 0,556, uji Nagelkerke sebesar 0,948, dan uji McFadden sebesar 0,919. Dilihat dari uji Nagelkerke sebesar 0,948 artinya faktor-faktor yang mempengaruhi tingkat kepuasan mahasiswa terhadap pemilihan program studi matematika UINSA Surabaya pada variabel independen sebesar 94,8\% dan 5,2\% dipengaruhi oleh faktor lain.

\section{E. Simpulan}

Model logit kumulatif dari regresi logistik ordinal terhadap faktor-faktor yang mempengaruhi tingkat kepuasan mahasiswa terhadap pemilihan program studi matematika UINSA Surabaya yaitu:
1. Logit $P\left(Y \leq j \mid X_{i}\right)=36,878+10,809 X_{1}+3,230 X_{2}+2,580 X_{3}+1,774 X_{4}+2,505 X_{5}+$ $1,795 \mathrm{X}_{6}$
2. Logit $P\left(Y \leq j \mid X_{i}\right)=63,878+10,809 X_{1}+3,230 X_{2}+2,580 X_{3}+1,774 X_{4}+2,505 X_{5}+$ $1,795 \mathrm{X}_{6}$ 
Faktor-faktor yang berpengaruh signifikan tingkat kepuasan mahasiswa terhadap pemilihan Program Studi Matematika UINSA Surabaya angkatan2016 s.d 2019 diantaranya yaitu fasilitas pendidikan,minat dan bakat danprospek program studi. Berdasarkan hasil dari uji Nagelkerke sebesar 0,948 artinya secara keseluruhan variabel independen mempengaruhi penilaian kepuasan mahasiswa terhadap pemilihan program studi matematika UINSA Surabaya sebesar 94,8\% dan $5,2 \%$ dipengaruhi oleh faktor lain.

\section{DAFTAR PUSTAKA}

Albana, M. (2013). Aplikasi regresi logistik ordinal untuk menganalisa tingkat kepuasan pengguna jasa terhadap pelayanan di stasiun Jakarta Kota. Skripsi, tidak dipublikasikan. Universitas Pakuan.

Al-Fattah, I. M. (2014). analisis faktor-faktor yang mempengaruhi masa studi lulusan mahasiswa program magister insitut teknologi sepuluh november (ITS) Surabaya menggunakan regresi logistik ordinal dan regresi probit ordinal. Skripsi, tidak dipublikasikan. Institut Teknologi Sepuluh Nopember.

Angreni, P. (2017). Analisis regresi logistik ordinal faktor-faktor yang mempengaruhi kecelakaan lalu lintas terhadap tingkat keparahan korban di Provinsi Bengkulu. Skripsi, tidak dipublikasikan. Universitas Bengkulu.

Bahtiar, R.Z., Asyiah, N., Rahmadhani, R., Ulinnuha, M., Arfian, A. \& Widodo, E. (2018). analisis pengaruh penggunaan laptop terhadap kesehatan mahasiswa FMIPA universitas islam Indonesia dengan regresi logistik ordinal. Prosiding Konferensi Nasional Penelitian Matematika dan Pembelajarannya (KNPMP) III 2018 yang diselenggarakan oleh Program Studi Pendidikan Matematika FKIP UMS. Surakarta: Universitas Muhammadiyah Surakarta.

Budyanra, B. \& Azzahra, G.N. (2015). Penerapan regresi logistik ordinal proportional odds model pada analisis faktor-faktor yang mempengaruhi kelengkapan imunisasi dasar anak balita di Provinsi Aceh. Media Statistika, 10(1), 37-47.

Maharani, S.H., Permanasari, L. \& Rohayati, R. (2018). Analisis faktor-faktor yang mempengaruhi keputusan mahasiswa dalam memilih jurusan administrasi bisnis politeknik negeri. Jurnal INTEKNA: Informasi, Teknik dan Niaga, 18(2), 111-117.

Martini. (2013). Analisa faktor-faktor yang mempengaruhi pemilihan jurusan akutansi sebagai tempat kuliah di perguruan tinggi. Jurnal Ekonomika dan Manajemen, 2(1), 1-20.

Mulyatini, S., Suharyati, \& Handayani, T. (2013). Faktor-faktor yang berpengaruh terhadap keputusan memilih program studi. Prosiding Seminar Internasional \& Call For Paper, $3(1), 1-15$.

Nalim. (2012). Analisis faktor yang mempengaruhi mahasiswa dalam memilih program studi pendidikan bahasa arab STAIN Pekalongan. Forum Tarbiyah, 10(2), 215-235.

Puspasari, M. A. (2017). Analisis regresi logistik ordinal. Skripsi, tidak dipublikasikan. Universitas Sanata Dharma.

Risnawati, E. \& Irwandi, S.A. (2012). Analisis faktor atas pengambilan keputusan mahasiswa untuk memilih jurusan akutansi di STIE perbanas Surabaya. The Indonesian Accounting Review, 2(1), 63-72.

Salamah, M. \& Setyarini, E.A. (2015). Analisis regresi logistik ordinal untuk mengetahui tingkat gangguan tunagrahita di Kabupaten Ponorogo Berdasarkan Faktor-faktor Internal Penyebab Tunagrahita. Jurnal Sains dan Seni ITS, 4(2), 163-168.

Syardiansah. (2017). Faktor-faktor yang mempengaruhi mahasiswa baru memilih program studi pada fakultas ekonomi universitas samudra. Jurnal Manajemen Dan Keuangan, 6(2), 788-797.

Wiliana, E. (2018). Analisis faktor-faktor yang mempengaruhi keputusan mahasiswa dalam memilih program studi di fakultas ilmu kesehatan universitas muhammadiyah Tangerang. Jurnal JKFT :Universitas Muhammadiyah, 3(1), 71-78. 
Fadillahtur Rizka Nur Rian \& Moch. Hafiyusholeh: Analisis Faktor-Faktor yang Mempengaruhi Tingkat Kepuasan Mahasiswa Terhadap Pemilihan Program Studi Matematika UINSA Surabaya Menggunakan Metode Regresi Logistik Ordinal

Zakariyah, Z. \& Zain, I. (2015). Analisis regresi logistik ordinal pada prestasi belajar lulusan mahasiswa di ITS berbasis SKEM. Jurnal Sains dan Seni ITS, 4(1), 121-126. 